\title{
Continuous GPS and broad-scale deformation across the Rhine Graben and the Alps
}

\author{
Journal Article \\ Author(s): \\ Tesauro, Magdala; Hollenstein, Christine; Egli, Ramon; Geiger, Alain; Kahle, Hans-Gert \\ Publication date: \\ 2005-09 \\ Permanent link: \\ https://doi.org/10.3929/ethz-b-000412581 \\ Rights / license: \\ In Copyright - Non-Commercial Use Permitted \\ Originally published in: \\ International Journal of Earth Sciences 94(4), https://doi.org/10.1007/s00531-004-0453-0
}




\section{Magdala Tesauro $\cdot$ Christine Hollenstein Ramon Egli · Alain Geiger · Hans-Gert Kahle \\ Continuous GPS and broad-scale deformation across the Rhine Graben and the Alps}

Received: 16 November 2003 / Accepted: 19 September 2004/Published online: 15 January 2005

(C) Springer-Verlag 2005

\begin{abstract}
In order to study the ongoing tectonic deformation in the Rhine Graben area, we reconstruct the local crustal velocity and the strain rate field from GPS array solutions. Following the aim of this work, we compile the velocities of permanent GPS stations belonging to various networks (EUREF, AGNES, REGAL and RGP) in central western Europe. Moreover, the strain rate field is displayed in terms of principal axes and values, while the normal and the shear components of the strain tensor are calculated perpendicular and parallel to the strike of major faults. The results are compared with the fault plane solutions of earthquakes, which have occurred in this area.

A broad-scale kinematic deformation model across the Rhine Graben is provided on the basis of tectonics and velocity results of the GPS permanent stations. The area of study is divided into four rigid blocks, between which there might be relative motions. The velocity and the strain rate fields are reconstructed along their borders, by estimating a uniform rotation for each block. The tectonic behaviour is well represented by the fourblock model in the Rhine Graben area, while a more detailed model will be needed for a better reconstruction of the strain field in the Alpine region.
\end{abstract}

Keywords Rhine Graben · GPS · Tectonics · Strain field $\cdot$ Geology

Magdala Tesauro: now at Faculty of Earth and Life Sciences, Vrije Universiteit Amsterdam, De Boelelaan 10851081 HV Amsterdam, e-mailmagdala.tesauro@falw.vu.nl

Ramon Egli: now at Institute for Rock Magnetism University of Minnesota, 291 Shepherd Laboratories, 100 Union Street, S.E. Minneapolis, MN 55455-0128

This revised version was published online in January 2005 with corrections to the e-mail address and a few other places.

M. Tesauro $(\bowtie) \cdot$ C. Hollenstein $\cdot$ R. Egli $\cdot$ A. Geiger

H.-G. Kahle

Geodesy and Geodynamics Laboratory,

ETH, Zürich, Switzerland

E-mail: Magdala.Tesauro@geod.baug.ethz.ch

\section{Introduction}

The work presented here has been carried out in the framework of the European Union funded ENTEC (ENvironmental TECtonics) research and training network and the EUCOR-URGENT (Upper Rhine Graben Evolution Neo Tectonics) project. We summarize the results of the GPS data analysis, but primarily focus on the kinematic interpretation. Our principal objective was to study and constrain the current crustal kinematic field of central western Europe, with special emphasis on the Rhine Graben area by investigating the velocity and the strain distribution.

Central western Europe is a geologically variable and complex area including structural units of different origin, evolution and recent activity. The Rhine Graben (Fig. 1) is a major element of the Cenozoic rift system of western and central Europe that extends from the shore of the North Sea via the Rhône-Bresse graben to the Mediterranean Sea over a distance of some 1,000 km (Fig. 1) (Ziegler 1992). It has been tectonically active since the late Eocene, when subsidence movements commenced, persisted until the middle Miocene in the southern part, and continued until the Pliocene and recent times in the northern part, under different stress regimes (Schumacher 2002). The current tectonic activity of this rift system is evident from historical earthquakes and by subsidence rates of up to $1 \mathrm{~mm} /$ year in the northern part (Zippelt and Mälzer 1981).

\section{Geological setting of the Rhine Graben area}

The Upper Rhine Graben has a length of $300 \mathrm{~km}$, a width of $30-40 \mathrm{~km}$ and it is characterized by a slightly sinuous configuration (Fig. 1). At the south, the Rhine Graben terminates near the city of Basle. At the northern end of the Upper Rhine Graben, at a triple junction near Frankfurt (Ziegler 1992), the rift system splits up: one branch follows the Hessen depression and the Leine Graben near Göttingen and then apparently disappears 
Fig. 1 Principal geological units of central western Europe. $B R$ Bresse-Rhône Depression, $V$ Vosges, $B F$ Black Forest, $U R G$ Upper Rhine Graben, $H G$ Hessen Graben, $L G$ Leine Graben, $R M$ Rhenish Massif, $E$ Eifel, LRE Lower Rhine Embayment, $E G$ Eger Graben

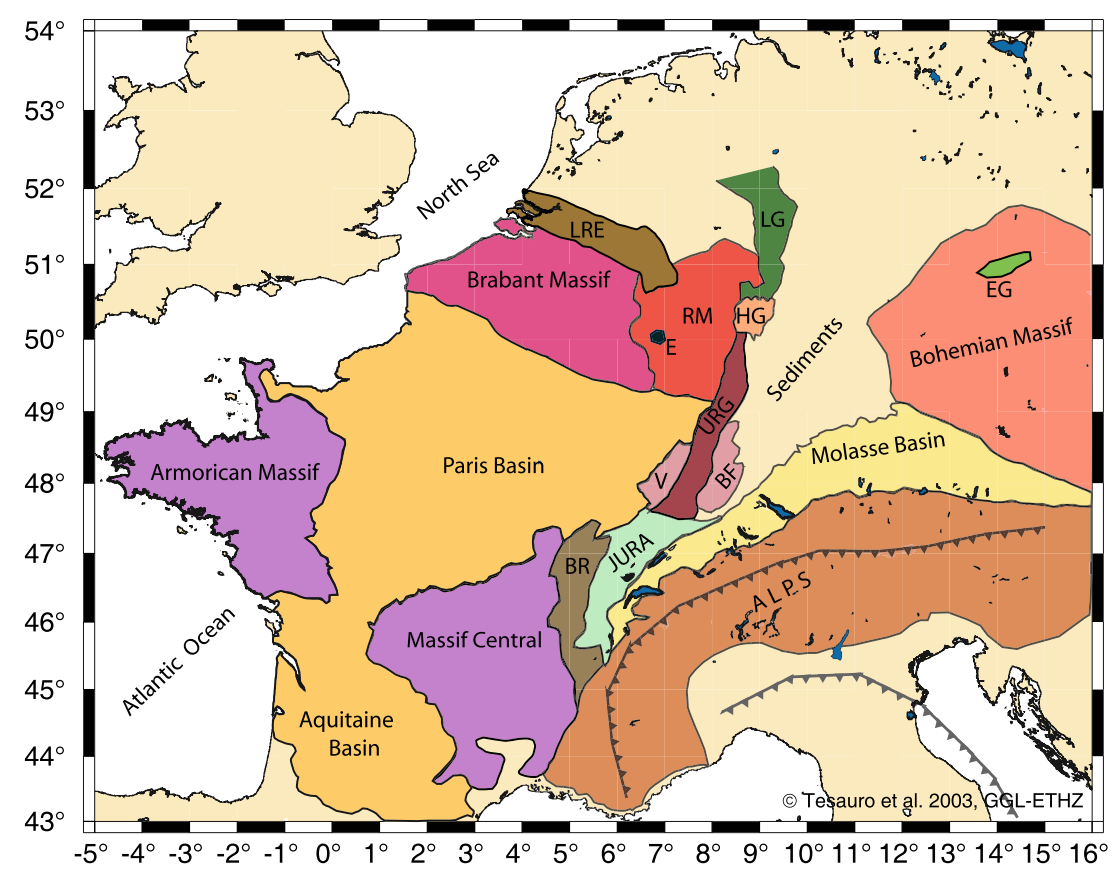

beneath the young sediments of the North German Plain (Fig. 1). The other branch of the rift system, which has been more active in recent times, continues northwestward through the Rheinish Massif into the Lower Rhine Embayment, changing orientation from $\mathrm{N} 20^{\circ} \mathrm{E}$ to a NW-SE direction (Ruhr Graben) (Ziegler 1992). From there it may be traced further to the shores of the North Sea (Ziegler 1992) (Fig. 1).

Rifting of the European Cenozoic rift system (ECRIS) started with graben subsidence in the southern Rhine Graben during the late Eocene, about $45 \mathrm{Ma}$ ago, under an extensional stress regime in the foreland of the Alpine orogenic belt (Ziegler and Dèzes, in this volume). The axis of maximum horizontal compressional stress rotated from NNE-SSW to a NNW-SSE and NW-SE direction about 20 Ma ago (Glahn and Granet 1992; Schumacher 2002). Graben subsidence ceased in the southern Rhine Graben and was followed by the midMiocene updoming of the Vosges-Black Forest complex (Laubscher 1982; Glahn and Granet 1992) (Fig.1). The doming was accompanied by volcanic activity more or less continuously throughout the Cenozoic, but peaked during the Miocene and again during the Quaternary in the Eifel area (Fig. 1). Shoulder uplift and subsidence of the graben, as reflected by its sedimentary infill, show a clear difference in the evolution of the northern part of the Upper Rhine Graben between Mainz and Heidelberg and the southern part between Strasbourg and Basle (Villemin et al. 1986; Glahn and Granet 1992). Today the southern Rhine Graben is characterized by small uplift/subsidence rates (Mälzer and Schlemmer 1975; Zippelt and Mälzer 1981), about +0.2 to $-0.1 \mathrm{~mm} /$ year (Ziegler 1992), which are not significant (Rózsa et al. this volume; Schlatter et al. this volume). Moreover, predominantly strike-slip mechanisms of earthquakes are derived from fault plane solutions
(Villemin et al. 1986; Bonjer 1997; Plenefisch and Bonjer 1997). In contrast, the northwestern branch of the Rhine rift, which crosscuts through the Rhenish Massif, is presently experiencing active rifting (Glahn and Granet 1992). Precision levelling indicates that this area is presently being uplifted at a rate of $0.4-0.6 \mathrm{~mm} / \mathrm{year}$, with maxima of more than $1 \mathrm{~mm} /$ year reached in the Eifel (Ziegler 1992) (Fig. 1). In the northern part of the Upper Rhine Graben, subsidence rates reach a maximum of $1 \mathrm{~mm} / \mathrm{yr}$ between Karlsruhe and Frankfurt (Ziegler 1992). The entire Rhine Graben system, as well as the Eger Graben located to the east, inside the Bohemian Massif (Fig. 1), are at present seismically active and have been the locus of some rather destructive historical earthquakes (Meghraoui et al. 2001).

\section{GPS data collection and data analysis}

In order to display the intraplate velocities in central western Europe, we used the dataset of the velocities of permanent GPS stations in the ITRF2000 reference frame that are processed at Swisstopo ${ }^{1}$ (in the following called "Swisstopo dataset"). The rates were determined for 53 GPS sites located in seven countries (Italy, Switzerland, Austria, Germany, France, Belgium and The Netherlands), representing the major structural units in central western Europe, and belonging to different networks (EUREF, AGNES, REGAL and RGP) ${ }^{2}$. These values were obtained on the basis of weekly solutions, calculated by processing the raw data with the Bernese software

\section{${ }^{1}$ Swiss Federal Office of Topography}

${ }^{2}$ European reference frame (EUREF), automated GPS network for Switzerland (AGNES), Réseau GPS permanent dans les Alpes (REGAL), Réseau GPS Permanent (RGP). 
(Beutler et al. 2001; Brockmann et al. 2001, 2002; E. Brockmann et al., in preparation). The length of the time series is not the same for all the stations. It varies between less than 2 up to more than 4 years (Table 1). Few stations, having unreliable values, or working since few months only, were excluded from the Swisstopo dataset. On the other hand, some ITRF2000 velocity values of EUREF stations (in the following called "EUREF dataset"), downloaded from EUREF website, showing a long and stable time series, were added, in order to have a more homogeneous distribution of the GPS sites. The integration was made applying to these new stations (BRUS, GOPE, KOSG, POTS and WSRT) a Helmert transformation straight on to the geocentric velocity values. Assuming that the transformation parameters do not change in time, we only have to estimate a rotation and a scale for transforming the velocities.

The velocity components of the new stations were computed using the following equation:

$$
\left[\begin{array}{l}
x_{i} \\
y_{i} \\
z_{i}
\end{array}\right]=\left[\begin{array}{ccc}
1+s & -r_{z} & r_{y} \\
r_{z} & 1+s & -r_{x} \\
-r_{y} & r_{x} & 1+s
\end{array}\right] \cdot\left[\begin{array}{l}
x_{j} \\
y_{j} \\
z_{j}
\end{array}\right]
$$

with $x_{i}, y_{i}, z_{i}$ and $x_{j}, y_{j}, z_{j}$ the new and the original geocentric velocity components, respectively, while $r_{x}, r_{y}$ and $r_{z}$ are the angles of small rotations about the $X, Y$ and $Z$ axes in radians and $l+s$ is the scale factor (unitless).

The values of the four parameters $\left(r_{x}, r_{y}, r_{z}\right.$ and $\left.s\right)$ were estimated by least-squares adjustment of Eq. 1 at seven stations common in the two datasets (BRST, GRAS, GRAZ, KOSG, TORI, WTZR, ZIMM), chosen on the basis of their distribution in the area of interest and on the data quality. The residuals obtained from the adjustment are displayed in Table 2 . We used the pole of rotation defined in Altamimi et al. (2002) for the Eurasian plate to calculate its motion, and we subtracted these velocity values from the ITRF2000 velocities to obtain the residuals with respect to the rotation of the Eurasian plate (Table 1 and Fig. 2). These residuals are called 'intraplate' velocities in this paper.

Due to the lack of reliable vertical components of GPS velocities, we considered only the horizontal velocity components, $V_{\text {north }}$ and $V_{\text {east }}$, respectively. The standard deviations, assumed equal for the two components, were calculated for each GPS permanent station on the basis of the length of the time span $(\sigma=1 \mathrm{~mm} / \sqrt{ }$ year $)$ (Table 1$)$.

The general movement of the GPS stations located between $4^{\circ}$ and $16^{\circ}$ of longitude is in the NW direction, with rates between 0.1 and $2.9 \mathrm{~mm} / \mathrm{year}$ (Table 1 and Fig. 2). Some stations located within Switzerland, differ from this general trend, possibly because of local effects (inset Fig. 2). The only two stations located within the Upper Rhine graben area (KARL and STRA) show small movements in $\mathrm{N}$ and $\mathrm{NW}$ direction $\left(V_{\mathrm{abs}}=0.81\right.$ and $0.34 \mathrm{~mm} /$ year), respectively. The stations located between $-5^{\circ}$ and $4^{\circ}$ of longitude, move in SW to $\mathrm{S}$ direction, with an absolute value of velocity between
$0.5 \mathrm{~mm} /$ year and $1.5 \mathrm{~mm} /$ year. Nevertheless, their velocity solutions, due to the shortness of time spans, could be unreliable.

On the basis of the velocity solutions, we calculated the strain rate field and displayed it as principal axes and values of the $2 \mathrm{D}$ strain rate tensor and as $2 \mathrm{D}$ dilatation rates (Figs. 3, 4). Moreover, we calculated the normal and the shear components of the strain tensor perpendicular and parallel to the Alpine boundary and to the eastern and western Rhine Graben borders (Figs. 5, 6). We can observe that the area where the highest compressional and extensional values were found corresponds to the Alpine zone. More concretely, we found relatively high values of compression in southwestern Switzerland and in southwestern Germany (about 12 nstrain $/$ year) ${ }^{3}$, oriented NW-SE (Figs. 3, 4). The areas of maximum extension are located in central Switzerland and western Austria with a maximum value of 7.5 nstrain/year (Figs. 3, 4). Moreover, relatively significant compressional and extensional strain rates are found perpendicular to the western and eastern Alpine chain, with maximum values of 5 and 6 nstrain/ year, respectively (Fig. 5). The shear strain rate is dextral along the central Alps and, less significant, sinistral in the eastern portion (Fig. 6). In the Rhine Graben area the strain rate values are within the margin of errors: both borders show low values of compression, about 2 nstrain/year (Fig. 5) and sinistral shear strain rates with maximum values of 2 nstrain/year (Fig. 6). However, the actual deformation cannot be assessed in this area on account of the sparse data available.

From the distribution of earthquakes (Fig. 7), we observe that most of them are located within three clusters: the Alpine chain, the Jura Massif-Rhine Graben area and the zone between the Armorican Massif and the Massif Central (Fig. 1). Earthquakes with relatively high magnitudes $(M>4.0)$ are mostly found in the Molasse basin (Figs. 7, 1).

Comparing the GPS strain rate field with seismic data, it is observed that the normal faulting tectonic regime, found in the Lower Rhine Graben area, fit well with the extensional strain domain seen in the trace of the $2 \mathrm{D}$ strain tensor (Figs. 7, 4). Furthermore, the dextral strikeslip found in the projection of the GPS strain field parallel to the strike of the central Alps coincides with the corresponding types of fault plane solutions (FPS) in this area (Figs. 6,7). On the other hand, the extension along the curvature of the Alpine arc, predicted by the FPS (Fig. 7) (Kastrup 2002; Kastrup et al. 2004), is not well represented in the GPS strain field (Fig. 3).

For further investigation of this apparent difference, longer observation time and higher density of stations are needed. This would also involve the consideration of the fact that the GPS data are possibly affected by local and spatially correlated noise. On the other hand, the concentration of the deformation on a limited number of

\footnotetext{
${ }^{3} 1 \mathrm{nstrain} /$ year corresponds to a change of distance of $1 \mathrm{~mm}$ per $1,000 \mathrm{~km}$ and year and is equivalent to $3.17 \times 10^{-17} / \mathrm{s}$.
} 
Table 1 Residuals values between the ITRF2000 velocities and the rotation of the Eurasian plate from the combination of the AGNES, EUREF, REGAL and RGP permanent GPS networks

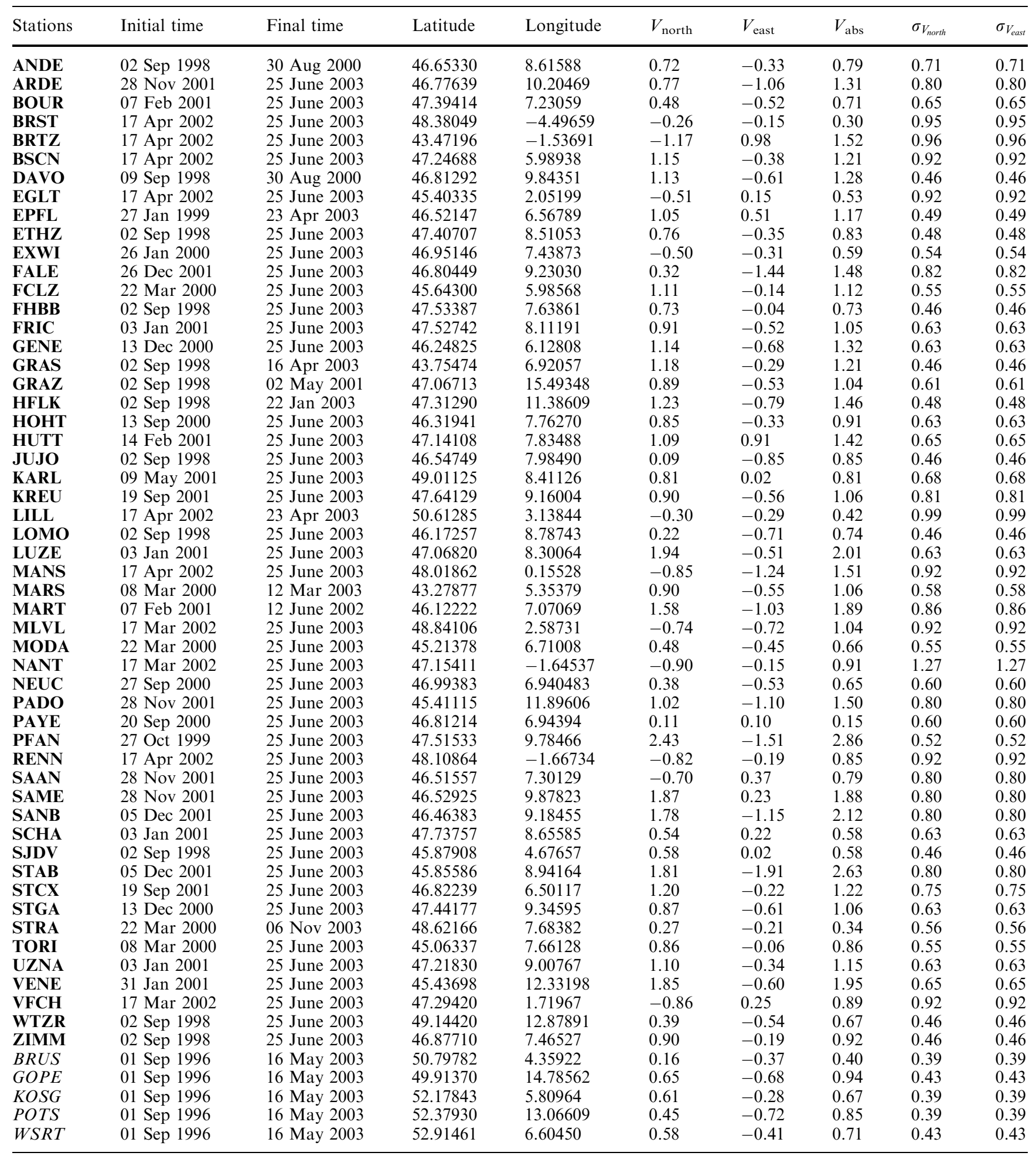

Bold and italic are the stations belonging to Swisstopo and EUREF datasets, respectively. Initial and final time of observation are displayed as day, month and year, Latitude and Longitude are expressed in decimal degree, $V_{\text {north, }} V_{\text {east }}, V_{\text {abs }}$,
$\sigma_{V}$ north and $\sigma_{V}$ east the horizontal velocity components, the absolute value of velocity and the standard deviations of the horizontal velocity components, respectively, in $\mathrm{mm} /$ year 
Table 2 Residuals of Helmert transformation expressed in $\mathrm{mm} /$ year for the three velocity components of the stations in common to Swisstopo and EUREF datasets

\begin{tabular}{llll}
\hline Stations & RES $x$ & RES $y$ & RES $z$ \\
\hline BRST & -0.59 & 0.15 & 0.44 \\
GRAS & 0.33 & -0.06 & -0.33 \\
GRAZ & -0.06 & 0.34 & -0.02 \\
KOSG & -0.19 & 0.07 & 0.15 \\
TORI & 0.13 & -0.22 & -0.11 \\
WTZR & -0.10 & 0.06 & 0.18 \\
ZIMM & 0.20 & -0.10 & -0.16 \\
\hline
\end{tabular}

active fault zones, as suggested by the distribution of seismicity (Fig. 7), makes it difficult to compare locally determined seismic strain with regional-scale displacements, which integrate strain over a large area.

At greater distances from the Alpine chain, basically beyond its foreland, the FPS show a mixture of predominantly strike-slip faulting (mostly in the Upper Rhine Graben), normal faulting (mostly in the Lower Rhine Graben) and some minor thrust faulting (http:// link.springer.de and Fig. 7), indicating a rather uniform NW-SE orientation of compression and NE-SW orientation of extension, probably related to the sea-floor spreading along the North Atlantic Ridge and the collision between the African and Eurasian plates (Müller et al. 1992; Plenefisch and Bonjer 1997; Kastrup 2002; Kastrup et al. 2004). These inferences from FPS data can be seen in the GPS data only in the south part of the ECRIS (Fig. 3), possibly on account of the low density of the stations in the north part of the area of study (Figs. 3 and 4).

\section{Four-block model}

In order to simulate the tectonic movement in central western Europe using the GPS data available, we propose a model, which divides the area of study into four rigid blocks between which there might be relative motions (Fig. 8). The borders of the blocks were defined on the basis of the differences between the velocity directions at the permanent GPS stations, and of earthquakes and fault distribution (Figs. 2, 7). The southeastern and northeastern block are located $\mathrm{S}$ and $\mathrm{N}$ of the Alpine zone, respectively, while the border between the northwestern and the southwestern block is represented by a band of seismicity connecting the Massif Central with the Armorican Massif, which separates the Paris Basin in the north from the Aquitaine Basin in the south (Figs. 1, 7). The division between the northeastern block and the two western blocks passes trough the BresseRhône Depression, the Upper Rhine Graben, the Rhenish Massif and the Lower Rhine Embayment, corresponding to the ECRIS (Fig. 1).

We calculated the horizontal components of velocity at the GPS points and at virtual points, taken $50 \mathrm{~km}$ on average close to the border of the blocks, by assuming a uniform rotation for each of the proposed blocks. The location of the pole of rotation and the angular velocity
Fig. 2 Velocities relative to Eurasia for the time period 1996-2003. White contour lines denote the national borders. Euler pole values for the rotation of Eurasia:

Lat $=57.965^{\circ}$,

Long $=-99.374^{\circ}, \omega=0.260^{\circ}$ Myear (Altamimi et al. 2002). The permanent GPS stations located between $4^{\circ}$ and $16^{\circ}$ of longitude show a movement in NW direction, the other ones, located between $-5^{\circ}$ and $4^{\circ}$ of longitude, move in SW to $\mathrm{S}$ direction

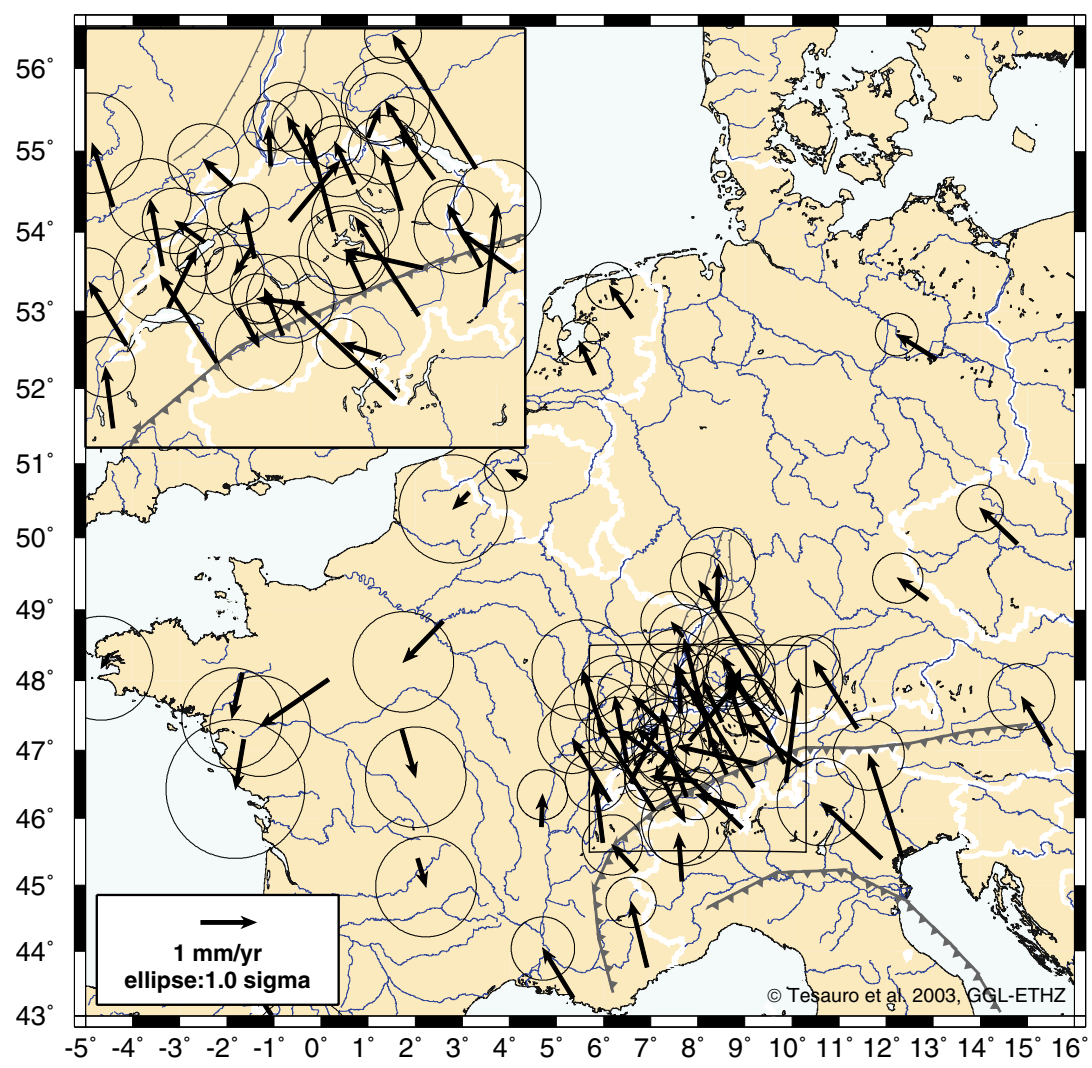


Fig. 3 Principal axes and values of strain rates obtained by leastsquares collocation (Straub 1996; Kahle et al. 2000). Covariance distance: $123 \mathrm{~km}$, sigma of signal: $0.85 \mathrm{~mm} /$ year. Compressional and extensional axes are in black and in white, respectively. White contour lines denote the national borders.

Noticeable compressional strain rates are located in

southwestern Switzerland and in southwestern Germany, where they reach values of up to 12 nstrain/year. The areas of maximum extension are found in central Switzerland and in western Austria with a maximum value of 7.5 nstrain/ year. No significant strain rates are found in the Rhine Graben area. The formal errors are between 4 and 7 nstrain/year
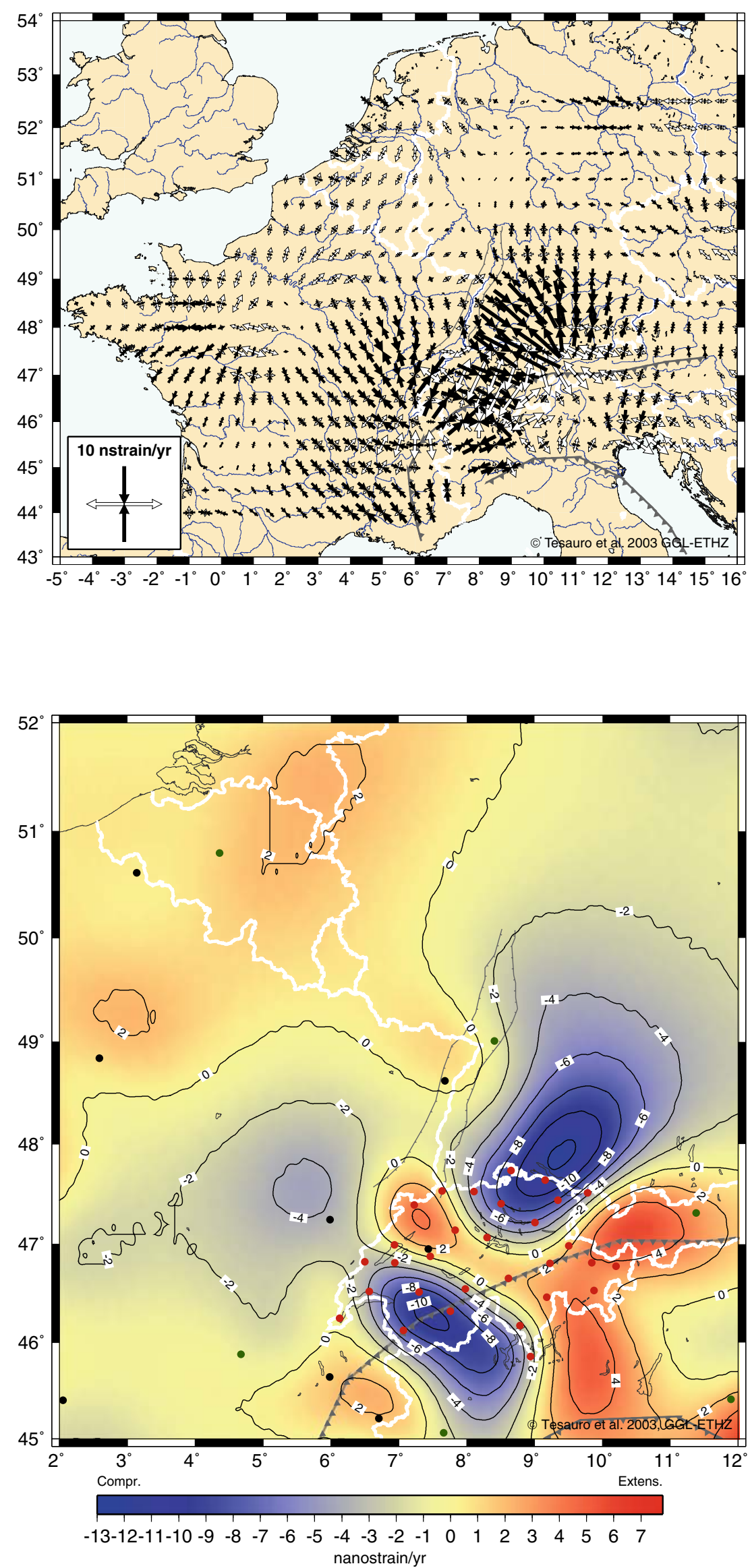

nanostrain/yr
Fig. 4 Two-dimensional dilatation rates in central western Europe calculated from the trace of the 2D strain rates tensor $\left(\varepsilon_{1}+\varepsilon_{2}\right)$. Covariance distance: $123 \mathrm{~km}$, sigma of signal: $0.85 \mathrm{~mm} /$ year. Red, green and black dots represent GPS permanent stations of the AGNES, EUREF and

REGAL-RGP networks, respectively. White contour lines denote the national borders. Relatively large compressional strain rates are found in southwestern Switzerland, in southwestern Germany, with maximum values of 12 nstrain/ year, while the centre of Switzerland and the western part of Austria are associated with extensional strain rates, with maximum values of 7 nstrain/year. No significant strain rates are found in the Upper Rhine Graben, while the Lower Rhine Graben is associated with small extensional strain rates. The formal errors are between 6 and 10 nstrain/year 
Fig. 5 Normal strain rate components calculated perpendicular to major fault zones. Covariance distance: $123 \mathrm{~km}$, sigma of signal: $0.85 \mathrm{~mm} /$ year. White contour lines denote the national borders. The eastern Rhine Graben border shows slightly higher compression than its western border, with a maximum value of 2 nstrain/ year. These values are within the margins of the formal errors, between 5 and 7 nstrain/ year. Relatively significant compression and extension can be observed perpendicular to the western and eastern Alpine boundary, with maximum values of 5 and 6 nstrain/year, respectively

Fig. 6 Shear strain rate components calculated along major faults zones. Covariance distance: $123 \mathrm{~km}$, sigma of signal: $0.85 \mathrm{~mm} /$ year. White contour lines denote the national borders. Sinistral shear is present along the eastern and western border of the Rhine Graben, with a maximum value of 2 nstrain/year, dextral shear along the centre of the Alpine boundary, and, less significant, sinistral shear in the eastern portions, with maximum values of 6 and 3 nstrain/year, respectively. The formal errors are between 3 and 5 nstrain/ year
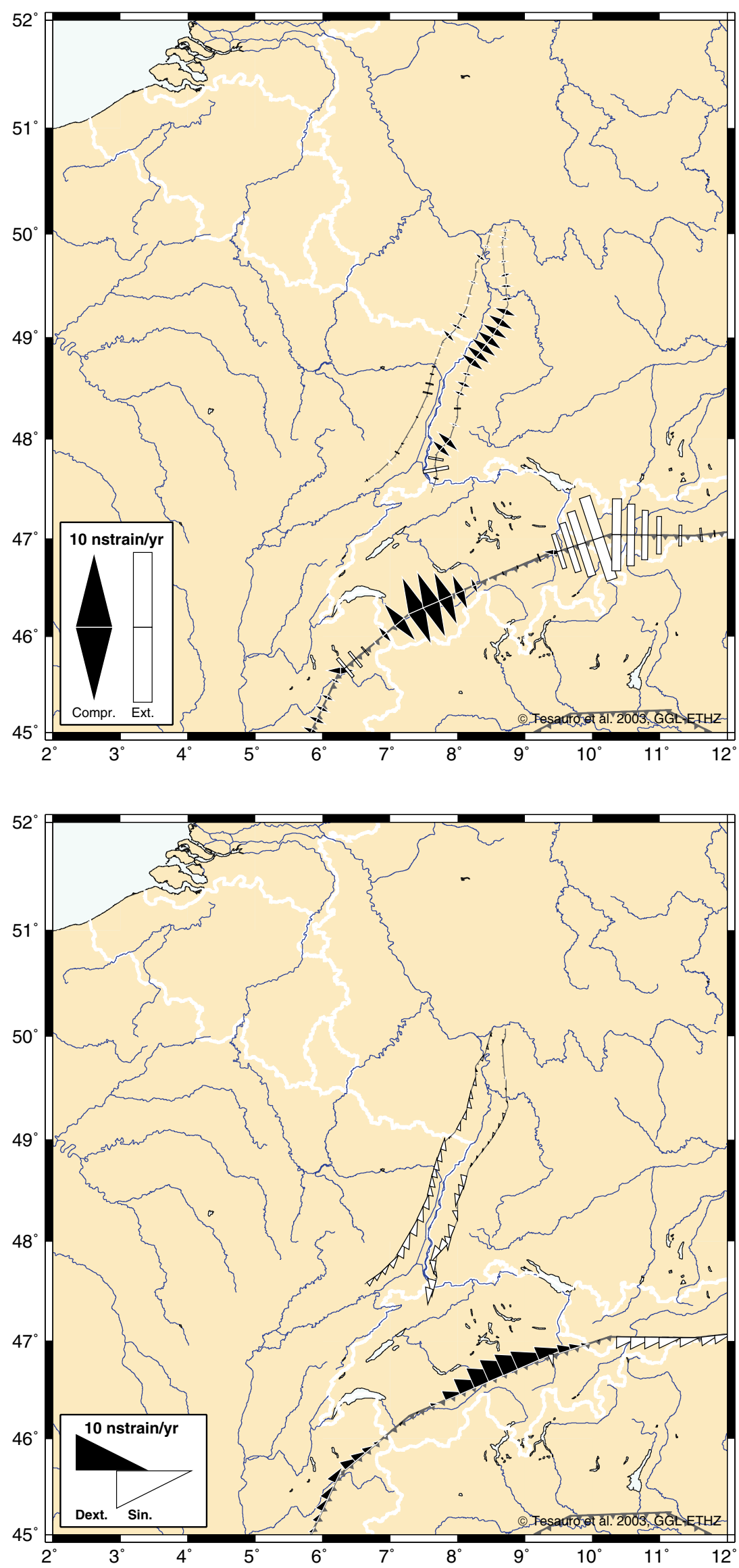


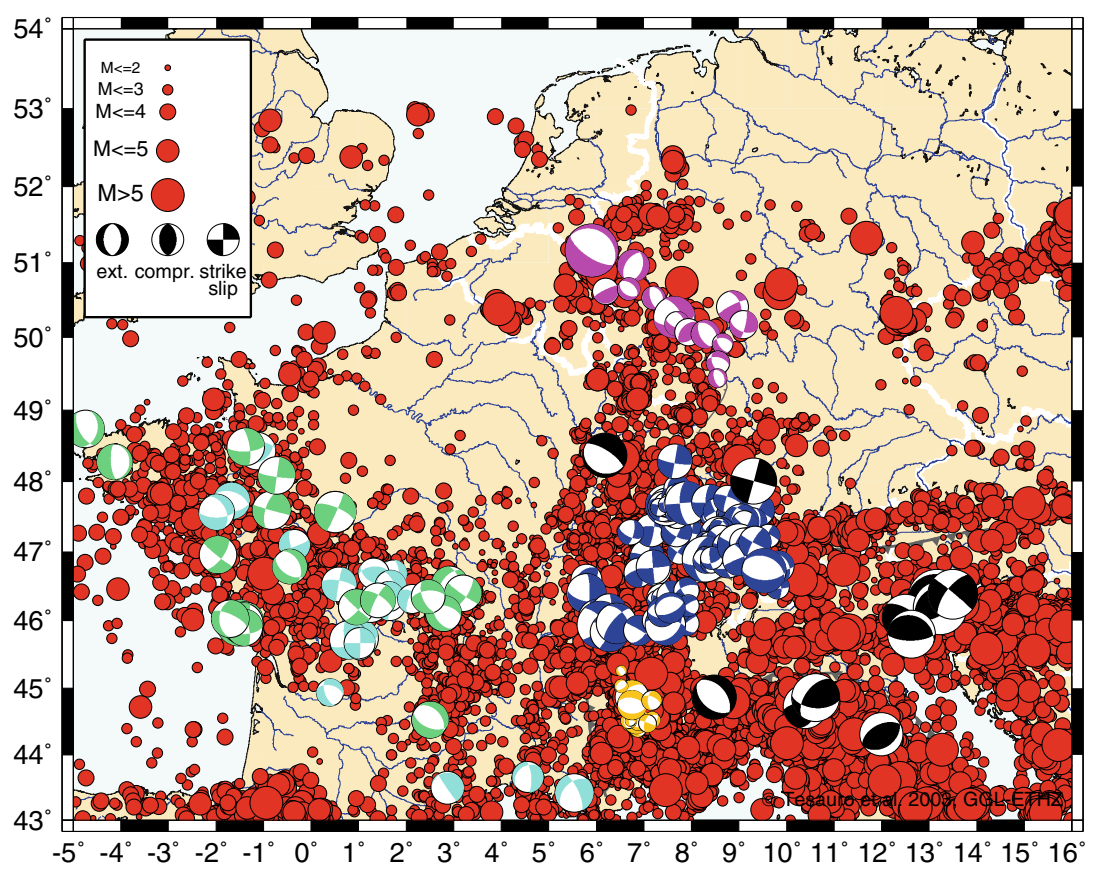

Fig. 7 Earthquakes in central western Europe since 1973 from the National Earthquake Information Center (NEIC) and focal mechanism solutions (FPS) since 1961 from Plenefisch and Bonjer 1997 (in violet ), Kastrup, 2002 (in blue ), Sue et al. 1999 (in yellow ), Nicolas et al. 1990 (in turquoise), Delouis et al. 1993 (in green ) and Harvard CMT Catalog (in black). White contour lines denote the national borders. Many earthquakes with $M>4.0$ are located in the Molasse basin. Focal mechanisms with normal fault plane solutions are present mostly in the Lower Rhine Graben, while with strike-slipe fault plane solutions are found mostly in the Alpine area, in the Upper Rhine Graben and in France, in the zone connecting the southern part of the Armorican Massif to the northwestern boundary of the Massif Central

for each block (Table 3 ) were estimated by least-squares adjustment (Geiger 2003), applying the following observation equation to each GPS point:

$$
\begin{aligned}
\boldsymbol{v}_{i} & =\omega \times \boldsymbol{r}_{i} \\
& =-\boldsymbol{r}_{i} \times \omega \\
& =\boldsymbol{R}_{i} \boldsymbol{\omega}
\end{aligned}
$$

with

$$
\boldsymbol{R}_{i}=-\boldsymbol{R}_{i}^{\mathrm{T}}
$$

The position vector is:

$\boldsymbol{r}_{i}^{T}=\left(r_{1 i}, r_{2 i}, r_{3 i}\right)$

and the corresponding skew symmetric matrix is:

$$
\boldsymbol{R}_{i}=\left(\begin{array}{ccc}
0 & r_{3 i} & -r_{2 i} \\
-r_{3 i} & 0 & r_{1 i} \\
r_{2 i} & -r_{1 i} & 0
\end{array}\right)
$$

Table 3 Location of pole of rotation, angular velocity and $\sigma_{0}$ aposteriori of the unit weight calculated for each block

\begin{tabular}{lllll}
\hline Blocks & Latitude & Longitude & $\omega$ & $\sigma_{0}$ \\
\hline SW & 47.7850 & 10.4980 & 0.0502 & 0.19 \\
SE & 35.7540 & -7.4030 & 0.0393 & 0.46 \\
NW & 23.5794 & 9.4148 & 0.0104 & 0.32 \\
NE & 29.6398 & -23.015 & 0.0144 & 0.51 \\
\hline
\end{tabular}

Latitude and Longitude are expressed in decimal degree, $\omega$ in deg/ Myear and $\sigma_{0}$ is unitless
The observation equations can be summarised in a system in the following way:

Number of observed points: $n$

Number of observation equations: $3 n$

Number on unknowns $(\omega): 3$

$$
\underbrace{\left(\begin{array}{c}
\boldsymbol{v}_{1} \\
\cdots \\
\cdots \\
\cdots \\
\boldsymbol{v}_{n}
\end{array}\right)}_{f}=\underbrace{\left(\begin{array}{c}
\boldsymbol{R}_{1} \\
\ldots \\
\cdots \\
\ldots \\
\boldsymbol{R}_{n}
\end{array}\right)}_{A} \omega
$$

Therefore, from the least-squares adjustment the rotation vector can be calculated as:

$\omega=\left(\boldsymbol{A}^{T} \boldsymbol{P} \boldsymbol{A}\right)^{-1} \boldsymbol{A}^{T} \boldsymbol{P} \boldsymbol{f}=\boldsymbol{N}^{-1} \boldsymbol{F}$

where $\boldsymbol{P}$ is the weight matrix of observations. If $\boldsymbol{P}=$ di$\operatorname{ag}\left[\boldsymbol{P}_{1}, \boldsymbol{P}_{2}, \boldsymbol{P}_{3}, \ldots, \boldsymbol{P}_{i}, \ldots, \boldsymbol{P}_{n}\right], \boldsymbol{N}$ and $\boldsymbol{F}$ can be evaluated by summing up over all points:

$$
\begin{aligned}
& \boldsymbol{N}=\sum_{i=1}^{n} \boldsymbol{R}_{i}^{T} \boldsymbol{P}_{i} \boldsymbol{R}_{i} \\
& \boldsymbol{F}=\sum_{i=1}^{n} \boldsymbol{R}_{i}^{T} \boldsymbol{P}_{i} \boldsymbol{v}_{i}
\end{aligned}
$$

The velocity vectors calculated for the northwestern and the northeastern block show different directions, 


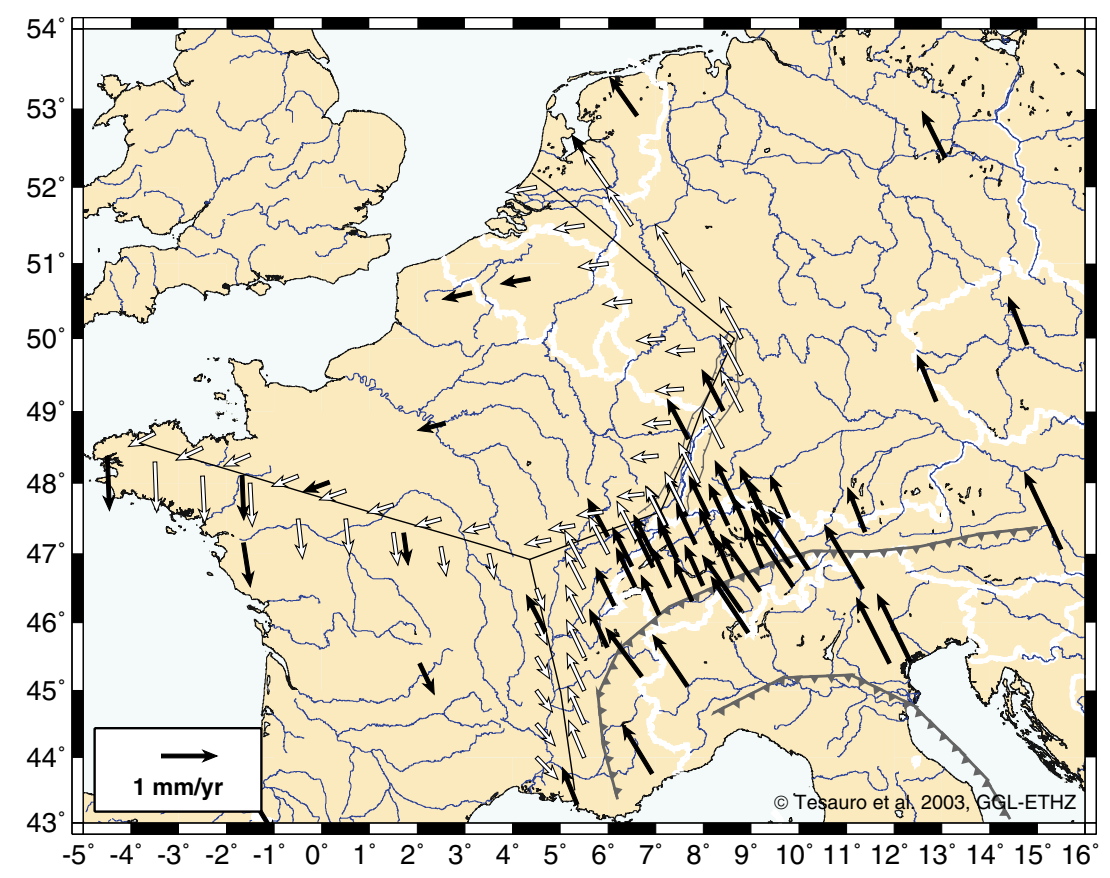

Fig. 8 Calculated velocities of crustal motion for the four-block model by least-squares estimation. The velocities at permanent GPS stations are shown as black arrows, while rates at virtual points, taken $50 \mathrm{~km}$ on average close to the border of the blocks, are shown as white arrows. The black lines represent the generalized borders between the northeastern, northwestern and the southwestern block, while the Alpine chain is taken as the border between the northeastern and the southeastern block. White contour lines denote the national borders. The velocity vectors of the northwestern and the northeastern block show different directions, WSW and NNW, respectively, while no difference in direction is found between the velocity vectors of the southeastern and the northeastern block. A change in the direction of the velocity vectors from WSW to SSE is observed between the northwestern and the southwestern block

WSW and NNW, respectively, while no difference in direction was found between the velocity vectors of the southeastern and the northeastern block. On the other hand, a change in the direction of the velocity vectors from WSW to SSE is observed between the northwestern and the southwestern block (Fig. 8). The horizontal components and the absolute values of velocity calculated for the four-block model are displayed in http://link.springer.de. The real data fit well with this model, as demonstrated by the relatively small values of $\sigma_{0}$ aposteriori ${ }^{4}$ of the unit weight, calculated for each block (Table 3). We observe that along the border corresponding to the ECRIS the northeastern block moves with a mean velocity of $0.76 \mathrm{~mm} /$ year, while the northwestern and the southwestern block seem to be associated with slightly slower movements, about 0.51 and $0.72 \mathrm{~mm} /$ year, respectively (http://link.springer.de).

On the basis of these new velocity solutions the strain rate field was calculated and displayed as principal axes

\footnotetext{
${ }^{4} \sigma_{0}$ or sigma aposteriori, is a statistical parameter related to the residuals between real and estimated velocity values. $\sigma_{0}=\frac{\sqrt{\sum P_{i} \operatorname{Res} x_{i}^{2}+P_{i} \operatorname{Res} y_{i}^{2}+P_{i} \operatorname{Resz} z_{i}^{2}}}{\sqrt{n-u}}$ where $P_{i}$ is the weight of the $I$-velocity, calculated as $P_{i}=\left(1 /\left(\sigma_{V_{\text {north }_{i}}^{2}}^{\sqrt{n-u}}+\sigma_{V_{\text {east }_{i}}^{2}}\right)\right)$ and $\sigma_{V_{\text {norh }_{i}}}$ and $\sigma_{V_{\text {east }}}$ the standard deviation for the two components of the horizontal velocity, that we assumed equal to $1 \mathrm{~mm} / \sqrt{y e a r} \operatorname{Res} x_{i}$, $\operatorname{Resy}_{i}, \operatorname{Resz}_{i}$ are the difference (residuals) between the real and calculated geocentric velocities with the four block model at the GPS stations, $n$ is the number of observations and $u$ the number of unknowns.
}

and values of the $2 \mathrm{D}$ strain rate tensors. Moreover, we calculated the normal and the shear strain components perpendicular and parallel to the strike of major faults (Figs. 9, 10, 11). We can observe that, although the blocks are supposedly rigid, small strain is still visible inside them, on account of the method of interpolation, least-squares collocation (Straub 1996; Kahle et al. 2000), used here to calculate it. This is an edge effect due to the correlation length ${ }^{5}$ chosen.

It can be clearly seen in Fig. 9 that the largest values of compression and extension are found in the southern and northern part of the Rhine Graben area, respectively. The eastern and the western borders of the Upper Rhine Graben show NW-SE compression in the south and $\mathrm{E}-\mathrm{W}$ extension in the north (Fig. 10). Along both borders sinistral shear is found (Fig. 11). These results, although not extremely well supported by the GPS data for the lack of permanent stations, seem to be consistent with the focal mechanisms (Fig. 7) and the current tectonic condition of this area, described in previous studies (Ahorner 1975; Larroque et al. 1987; Larroque and

\footnotetext{
${ }^{5}$ The correlation function defines the interrelationship between different points observed. Normally, the influence of a distant point should be smaller and the value of the function usually decreases with a growing distance and converges to zero. Therefore, if a correlation length is chosen too short the values observed remain isolated, while if it is too long, the field derived becomes extremely smooth. However, a correlation length should not be smaller than the average distance between the stations (Straub 1996).
} 
Fig. 9 Principal axes and values of strain rates reconstructed from the velocity field for the four-block model, using the least-squares collocation (Straub 1996; Kahle et al. 2000). Covariance distance: $77 \mathrm{~km}$, sigma of signal: $0.56 \mathrm{~mm} /$ year. Compressional and extensional axes are in black and in white, respectively. The black lines represent the generalized borders between the northeastern, northwestern and the southwestern block, while the Alpine chain is taken as the border between the northeastern and the southeastern block. White contour lines denote the national borders. The highest values of strain rates are found along the border between the eastern and the western blocks

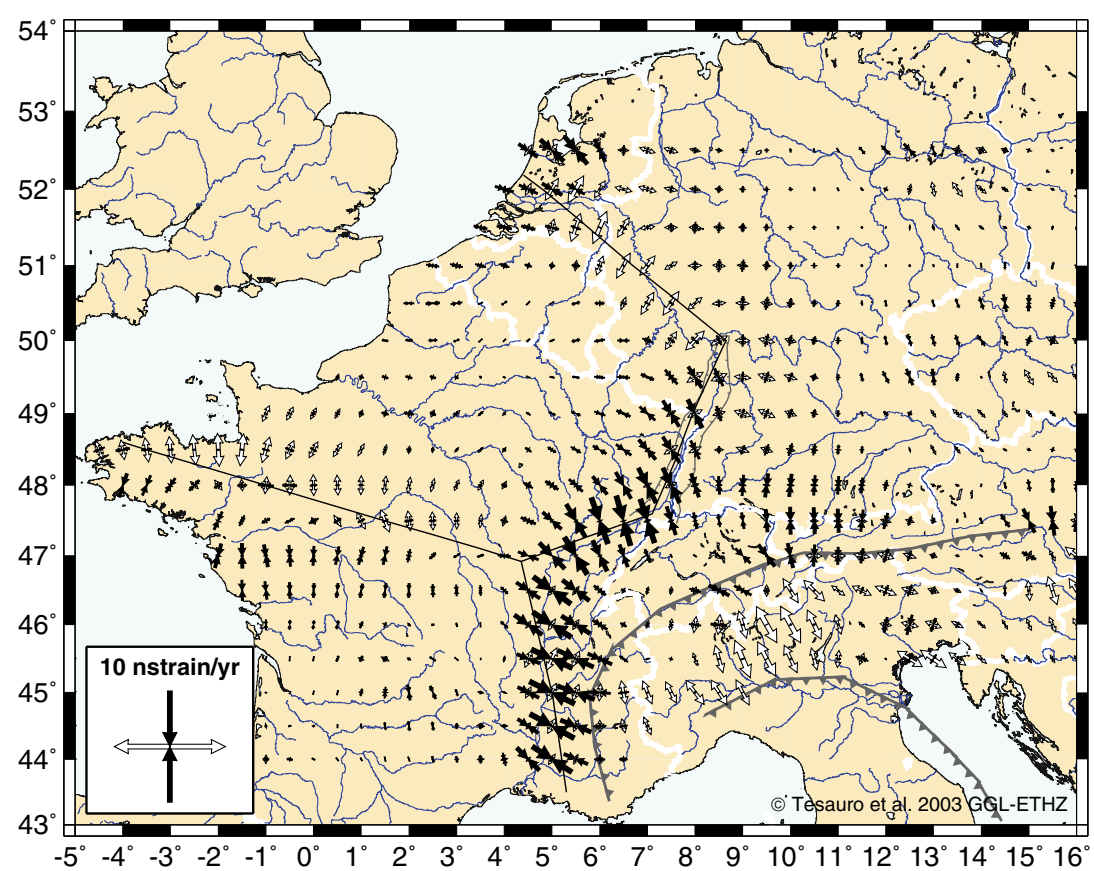

Laurent 1988; Müller et al. 1992; Delouis et al. 1993; Bonjer 1997; Plenefisch and Bonjer 1997; Schumacher 2002; Behrmann et al. 2003; Giamboni et al. 2004; Ziegler and Dèzes, in this volume), supporting the difference in the evolution between the northern and the southern part of the Rhine Graben system (Glahn and
Granet 1992; Villemin et al. 1986). The transition from a compressional to an extensional regime occurs in the region where the Rhine Graben system changes its orientation from SW-NE to SE-NW direction (Figs. 1, 9). The observed directions of the principal values of strain axes are in agreement with those derived from focal
Fig. 10 Normal strain rate components, calculated for the four-block model, projected perpendicular to major fault zones. Covariance distance: $77 \mathrm{~km}$, sigma of signal: $0.56 \mathrm{~mm} /$ year. The black lines represent the generalized borders between the northeastern, northwestern and the southwestern block, while the Alpine chain is taken as the border between the northeastern and the southeastern block. White contour lines denote the national borders. The southwestern Rhine Graben border shows slightly higher compression along NE-SW oriented segments of the faults line, while north oriented segments are in extension. Small compression is found perpendicular to the Alpine boundary

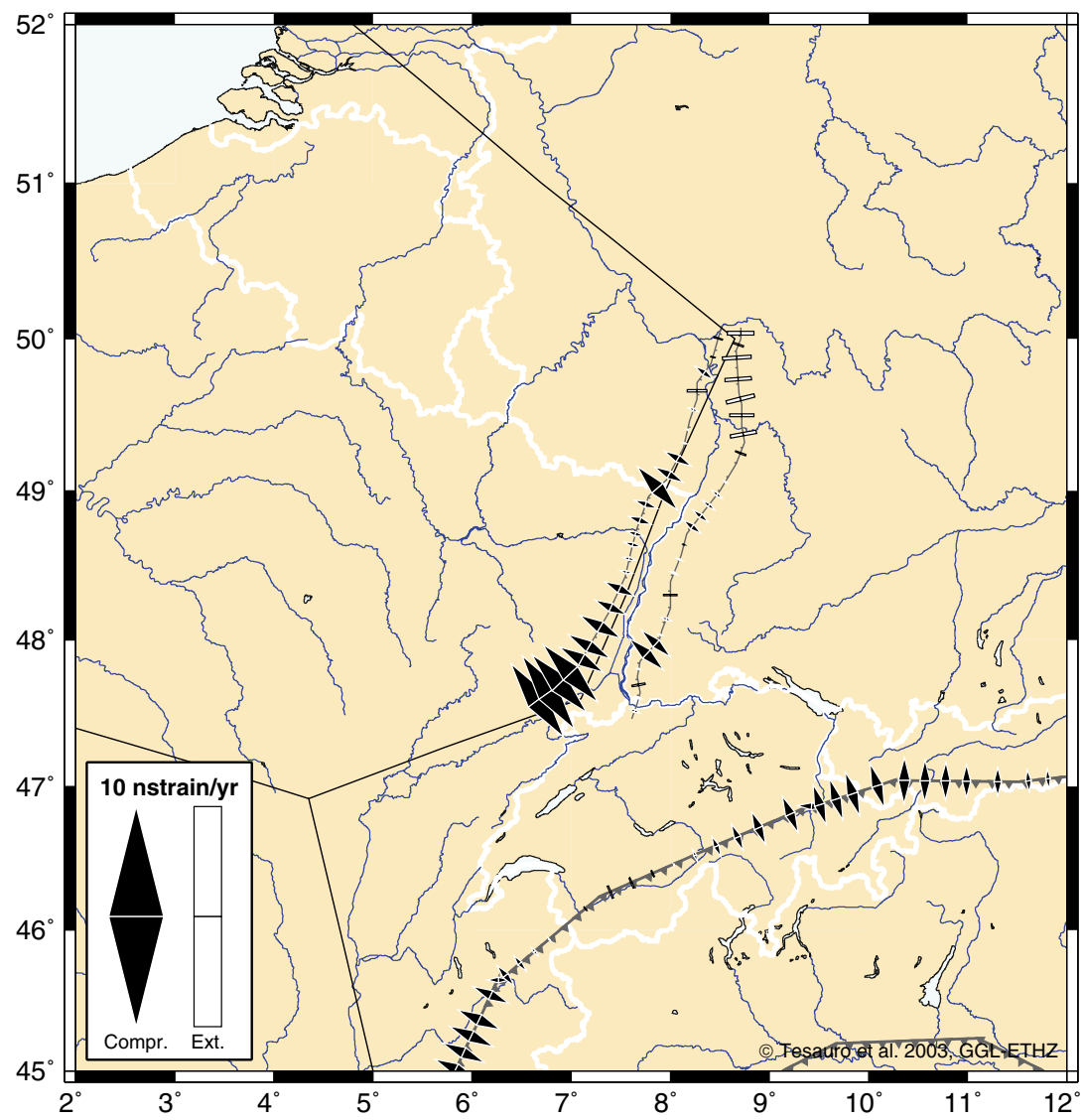


Fig. 11 Shear strain rate components, calculated for the four-block model, projected parallel to major fault zones. Covariance distance: $77 \mathrm{~km}$, sigma of signal: $0.56 \mathrm{~mm} /$ year. The black lines represent the generalized borders between the northeastern, northwestern and the southwestern block, while the Alpine chain is taken as the border between the northeastern and the southeastern block. White contour lines denote the national borders. Sinistral shear is present along the eastern and western border of the Rhine Graben, while shear strain along the Alpine boundary is negligible

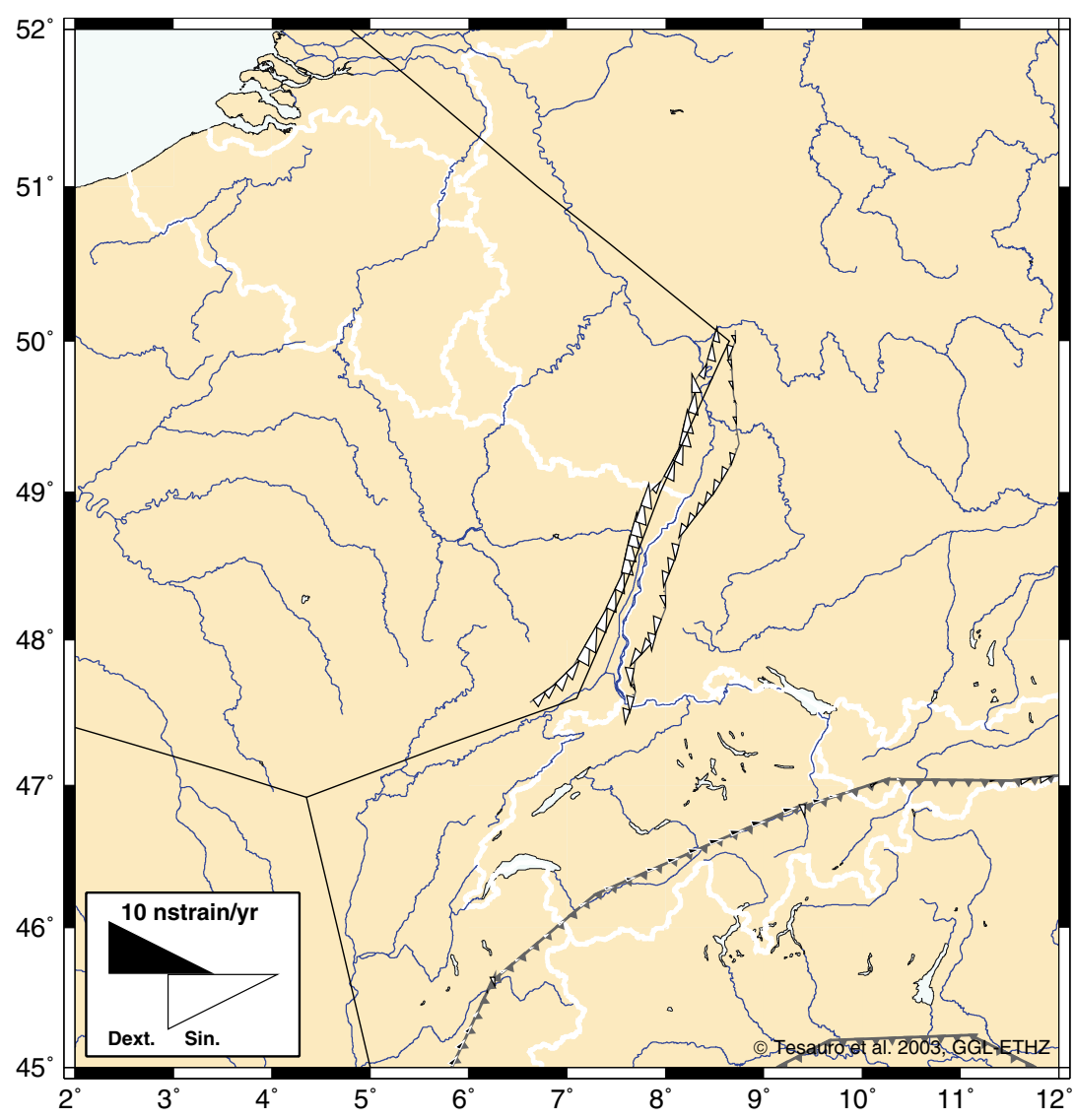

mechanisms (Figs. 7, 9). The compression shows a decrease from the Upper to the Lower Rhine Graben (Fig. 9), according to the tectonic knowledge of the area (Delouis et al. 1993).

Low values of strain rates are found along the Alpine chain (Figs. 9, 10, 11), because the GPS points located in the northeastern and in the southeastern block move in the same direction (NW), although with slightly different absolute values of velocity (http://link.springer.de). These results differ from those which are seen in the FPS (Fig. 7) and in the geophysical data (Eva et al. 1997, 1998; Eva and Solarino 1998; Sue et al. 1999; Calais et al. 2000, 2002; Kastrup 2002; Vigny et al. 2002; Sue and Tricart 2003; Delacou et al. 2004; Kastrup et al., 2004), both supporting the presence of relative high stress and strain in this area. Therefore, the four-block model can simulate the regional strain field with a good approximation, but is unable, at the moment, to represent the complex tectonic condition characterizing the Alpine collision zone. However, the strain displayed in Fig. 3, in our opinion, does not reflect completely the complex tectonic situation present there. To have a better definition of the strain distribution a shorter correlation length should be used and, in this way, the model might be suitable also for the Alpine area. Nevertheless, this other approach implies to separate the study of the Alps from the study of the Rhine Graben (where the low density of the network does not allow to reduce the correlation length), while we preferred to make a unique general analysis for central western Europe. For the same reason, we did not consider the tectonic movements in the eastern Alps, related to the Adria-Europe convergence, since a more specific study is required, which is hardly possible at the moment owing to the low number of GPS stations located in this area.

Relatively small values of extensional strain rates were found along the border separating the northwestern from the southwestern block, on account of the small velocity values estimated in this zone (Figs. 8, 9). On the other hand, numerous geological and geophysical properties exhibit a real continuity throughout the Massif Central and the Armorican Massif (Fig. 1), while the focal mechanisms (Fig. 7 and http://link.springer.de) show a strike-slip tensile regime (Nicolas et al. 1990; Delouis et al. 1993), compatible with the homogeneous stress field found in the Rhine Graben area $\left(\sigma_{1}\right.$ and $\sigma_{3}$ NW-SE and NE-SW oriented) (Delouis et al. 1993).

We did not make any quantitative analysis of the strain obtained from our model, since different numerical results are possible depending on the virtual points location. However, we made additional tests changing the number and the distribution of them in the area of study. We proved that also when we use a dense grid of virtual points the results of the simulation remain basically the same (http://link.springer.de): as in Fig. 9, the highest values of compression and extension are present along the borders corresponding to the ECRIS, where larger changes in the velocity values and directions are 
observed. Moreover, we can notice that a higher density of virtual points produces an increase of strain values along all the borders of the blocks. In particular, the Alps show a compressional strain pattern NW-SE oriented in the western part and NNW-SSE in the eastern part (http://link.springer.de). This rotation of the strain axes direction along the Alpine arc was first observed by Pavoni (1980) and attributed to the ongoing AfricanEurasian plate convergence (Bassi et al. 1997; Bada et al. 1998; Grenerczy et al. 2000). On the other hand, inside the blocks the strain tends to reduce to zero and the 'artificial' extension present in the southeastern block in Fig. 9, due to the inhomogeneous density of points, is not visible anymore (http://link.springer.de).

\section{Conclusions and outlook}

From a selected set of European continuous GPS networks, we calculated the present strain rate field and compared it with seismic data. Overall, relatively small strain rates have been found, the values of which are close to the margin of errors inherent to the current GPS technology. Nevertheless, it was possible to distinguish between different general trends of the horizontal velocity field. Therefore, we attempted to model the tectonic deformation, considering also the geological setting and the distribution of earthquakes. For this purpose, we divided the area of study into four rigid blocks (northwestern, northeastern, southwestern and southeastern block, respectively), between which there might be relative motions. In this way, we reconstructed the velocity and the strain rate fields along the borders of the blocks, by estimating a uniform rotation for each block (Fig. 8, 9, 10, 11).

The results, in terms of velocities and strain rates, found along the border corresponding to the ECRIS (Figs. 8, 9 and http://link.springer.de), are consistent with the geological observations and seismic data shown in previous studies (Ahorner 1975; Larroque et al. 1987; Larroque and Laurent 1988; Müller et al. 1992; Delouis et al. 1993; Bonjer 1997; Plenefisch and Bonjer 1997; Schumacher 2002; Behrmann et al. 2003; Giamboni et al. 2004; Ziegler and Dèzes, in this volume). We observe a change from a NW-SE oriented compressional regime in the Upper Rhine Graben, to an extensional regime in the Rhenish Massif and the Lower Rhine Graben (Fig. 9). Moreover, sinistral shear is found along both borders of the Rhine Graben (Fig. 11).

In the model presented, compressional strain rates are observed along the Alpine zone with a small counterclockwise rotation of the strain axes from NW-SE to NNW-SSE direction (http://link.springer.de), according to previous authors (Bassi et al. 1997; Bada et al. 1998; Grenerczy et al. 2000). On the other hand, arc-parallel extension, visible from the FPS in the western part of the Alps (Fig. 7), is neither evident in the four-block model (Fig. 9 and http://link.springer.de) nor in the real data, showing compression NW-SE oriented (Fig. 3).
Therefore, an improvement of the significance of the GPS results with longer time spans is required, in order to eliminate local and possible spatially correlated noise between the stations. Moreover, a more detailed model, integrating also the current uplift observed in the Alpine area, is needed to reconstruct the complex strain rate field, which results from a superimposition of a local stress, probably due to a lateral density variation in the lithosphere, on the regional stress, caused by plate boundary forces (Sue et al. 1999; Kastrup 2002; Sue and Tricart 2003; Delacou et al. 2004; Kastrup et al. 2004).

Along the border connecting the Massif Central with the Armorican Massif, a change in the direction of the velocity vectors (from WSW to SSE) is seen and small values of extensional strain rates are found (Figs. 8, 9 and http://link.springer.de). Nevertheless, although a change in the velocity and strain field is realistic in this zone, characterized by numerous earthquakes, we need more GPS stations and longer time series to support these results.

Acknowledgments We would like to thank Nicholas Deichmann of the Swiss Seismological Service for the helpful discussions and for providing the program to convert the azimuth and dip values of $\mathrm{P}$ and $\mathrm{T}$ axes to azimuth dip and rake values of the principal planes of focal mechanisms. We wish to thank the two reviewers Malte Westerhaus of Karlsruhe University and Stefan Schmid of Basel University, for helpful comments that improved the manuscript. Funds were kindly provided by EU grant HPRN-2000-00053 (Swiss Federal Office of Science and Education, BBW $\mathrm{N}_{0}$. 99-0567-2) within the framework of the project ENTEC.

\section{References}

Ahorner L (1975) Present-day stress field and seismotectonic block movements along major fault zones in central Europe. Tectonophysics 29:233-249

Altamimi Z, Sillard P, Boucher C (2002) ITRF2000: A new release of the International Terrestrial Reference Frame for earth science applications. J Geophys Res 107, B10 2214:1-19

Bada G, Cloetingh S, Gerner P, Horvath F (1998) Sources of recent tectonic stress in the Pannonian region: inferences from finite element modeling. Geophys J Int 91:937-983

Bassi G, Sabadini R, Rebaii S (1997) Modern Tectonic regime in the Tyrrenian area: observations and models. Geophys $\mathbf{J}$ Int 129:330-346

Behrmann JH, Hermann O, Horstmann M, Tanner DC, Bertrand G (2003) Anatomy and kinematics of oblique continental rifting revealed: a three-dimensional case study of the southeast Upper Rhine graben (Germany). AAPG Bull 87(7):1105-1121

Beutler G, Bock H, Brockmann E, Dach P, Fridez P, Gurtner W, Hugentobler U, Ineichen D, Johnson J, Meindl M, Mervart L, Rothacher M, Schaer S, Springer T, Weber R (2001) In: Hugentobler U, Shaer S, Fridez P (eds) Bernese GPS Software Version 4.2. Astronomical Institute, University of Berne

Bonjer K-P (1997) Seismicity pattern and style of seismic faulting at the eastern borderfault of the southern Rhine Graben. Tectonophysics 275:41-69

Brockmann E, Grünig S, Schneider D, Wiget A, Wild U (2001) Introduction and first applications of a Real Time Precise Positioning Service using the Swiss Permanent Network 'AGNES'. National report of Switzerland: In: Torres JA, Hornik H (eds) Subcommission for the European Reference Frame (EUREF). Dubrovnik, 2001 
Brockmann E, Grünig S, Schneider D, Wiget A, Wild U (2002) Applications of the real-time Swiss GPS permanent network AGNES. In Proceedings of the EGS XXVII general assembly, Nice, 21-26 April 2002, Session 9 on Evolving Space Geodesy Techniques, Physics and Chemistry of the Earth

Calais E, Gallison L, Stéphan J-F, Delteil J, Deverchere J, Larroque C, Mercier De Lépinay B, Popoff M, Sosson M (2000) Crustal strain in the Southern Alps, France, 1948-1998. Tectonophysics 319:1-17

Calais E, Noquet J-M, Jouanne F, Tardy M (2002) Current strain regime in the Western Alps from continuous Global Positioning System measurements, 1996-2001. Geology 30(7):651-654

Delacou B, Sue Ch, Champagnac JD, Burkhard M (2004) Presentday geodynamics in the bend of the western and central Alps as constrained by earthquake analysis. Geophys J Int 158:753-774

Delouis B, Haessler H, Cisternas A, Rivera L (1993) Stress tensor determination in France and neighbouring regions. Tectonophysics 221:413-438

Eva E, Solarino S, Eva C, Neri G (1997) Stress tensor orientation derived from fault plane solutions in the southwestern Alps. J Geophys Res 102(B4):8171-8185

Eva E, Pastore S, Deichmann N, (1998) Evidence for ongoing extensional deformation in the western Swiss Alps and thrustfaulting in the southwestern Alpine Foreland. J Geodynam 26(1):27-43

Eva E, Solarino S (1998) Variations of stress directions in the western Alpine arc. Geophys J Int 135:438-448

Geiger A (2003) Präzisionsnavigation. Lecture Notes Geomatics, ETH Zürich

Giamboni M, Ustaszewski K, Schmid SM, Schumacher ME, Wetzel A (2004) Plio-Pleistocene transpressional reactivation of Paleozoic and Paleogene structures in the Rhine-Bresse transform zone (northern Switzerland and eastern France). Int $\mathbf{J}$ Earth Sci 93(2):207-223

Glahn A, Granet M (1992) 3-D structure of the lithosphere beneath the southern Rhine Graben area. Tectonophysics 208:149-158

Grenerczy G, Kenyeres A, Fejes I (2000) Present crustal movement and strain distribution in Central Europe inferred from GPS measurements. J Geophys Res 105(B9):21835-21846

Kahle H-G, Cocard M, Peter Y, Geiger A, Reilinger R, Barka A, Veis G (2000) GPS-derived strain field within the boundary zones of the Eurasian, African, and Arabian Plates. J Geophys Res 105(B10): 23353

Kastrup U. (2002) Seismotectonics and stress field variations in Switzerland. PhD Thesis, no. 14527, ETH Zürich

Kastrup U, Zoback ML, Deichmann N, Evans KF, Giardini D, Andrew JM (2004) Stress field variations in the Swiss Alps and the northern Alpine foreland derived from inversion of fault plane solutions. J. Geophys Res 109(B1):B01402

Larroque JM, Laurent PH (1988) Evolution of the stress field pattern in the south of the Rhine Graben from the Eocene to the present. Tectonophysics 148:41-58

Larroque JM, Etchecopar A, Philip H (1987) Evidence for the permutation of stresses $\sigma_{1}$ and $\sigma_{2}$ in the Alpine foreland: the example of the Rhine Graben. Tectonophysics 144:315-322

Laubscher H (1982) Die Südostecke des Rheingrabens-ein kinematisches und dynamisches Problem Eclogae Geol. Helvetica 75:101-116
Mälzer H, Schlemmer H (1975) Geodetic measurements and recent crustal movements in the southern upper Rhinegraben. Tectonophysics 29:275-282

Meghraoui M, Delouis B, Ferry M, Giardini D, Huggenberger P, Spottke I, Granet M (2001) Active normal faulting in the Upper Rhine Graben and Paleoseismic identification of the 1356 basel earthquake. Science 293:2070-2073

Müller B, Zoback ML, Fuchs K, Mastin L, Grgersen S, Pavoni N, Stephanson O, Ljundggren C (1992) Regional pattern of tectonic Stress in Europe. J Geophys Res 97(B8):11783-11803

Nicolas M, Santoire JP, Delpech PY (1990) Intraplate seismicity: new seismotectonic data in Western Europe. Tectonophysics 179:27-53

Noquet JM, Calais E (2003) Crustal velocity field of western Europe from permanent GPS array solutions, 1996-2001. J Geophys Res $154: 72-88$

Pavoni N (1980) Crustal stresses inferred from fault-plane solutions of earthquakes and neotectonic formation in Switzerland. Rock Mech Suppl 9:63-68

Plenefisch T, Bonjer KP (1997) The stress field in the Rhine graben area inferred from earthquake focal mechanisms and estimation of frictional parameters. Tectonophysics 275:71-97

Rózsa Sz, Heck B, Mayer M, Seitz K, Westerhaus M, Zipelt K (2003) Determination of displacements in the Upper Rhine Graben area from GPS and levelling data. Int J Earth Sci (this issue)

Schlatter A, Schneider D, Geiger A, Kahle H-G (2003) Recent vertical movements from precise levelling in the vicinity of the city of Basle, Switzerland. Int J Earth Sci (this issue)

Schumacher ME (2002) Upper Rhine Graben: Role of preexisting structures during rift evolution. Tectonics 21, 1,1006:1-17

Straub Ch. (1996) Recent crustal deformation and strain in the Marmara Sea region, NW Anatolia inferred from GPS Measurements. Ph.D. thesis, ETH Zürich

Sue C, Thouvenot F, Fréchet J, Tricart P (1999) Widespread extension in the core of the western Alps revealed by earthquake analysis. J Geophys Res 104(B11):25611-25622

Sue C, Tricart P (2003) Neogene to ongoing normal faulting in the inner western Alps: a major evolution of the late alpine tectonics. Tectonics 22, 5, 1050:1-25

Vigny C, Chéry J, Duquesnoy T, Jouanne F, Amman J, Anzdei M, Avouac J-P, Barlier F, Bayer R, Briole P, Calais E, Cotton F, Duquenne F, Feigl KL, Ferhat G, Flouzat M, Gamond J-F, Geiger A, Harmel A, Kasser M, Laplanche M, Le Pape M, Martinod J, Ménard G, Meyer B, Ruegg J-C, Scheubel J-M, Scotti O, Vidal G (2002) GPS network monitors the Western Alps' deformation over a five-year period: 1993-1998. J Geodesy 76:63-76

Villemin T, Alvarez F, Angelier J (1986) The Rhinegraben: extension, subsidence and shoulder uplift. Tectonophysics 128:47-59

Ziegler PA (1992) European cenozoic rift system. Tectonophysics 208:91-111

Ziegler PA, Dèzes P (2003) The Rhine rift system: evolution of the lithosphere. Int $\mathbf{J}$ Earth Sci (in this issue)

Zippelt K, Mälzer H (1981) Recent height changes in the central segment of the Rhinegraben and its adjacent shoulders. Tectonophysics $73: 119-123$ 